Final version with authorial corrections. Not for quotation without permission.

birgit.kellner@oeaw.ac.at

Birgit KeLlNER

\title{
Vernacular Literacy in Tibet: Present Debates and Historical Beginnings ${ }^{1}$
}

The rise of vernacular literacy - what does this mean, and how can it be meaningfully conceptualized? We might conceive of vernacularization as the phenomenon that communities begin to write literature in the language where it requires the least effort for them, in the (or a) language that they speak at home, in everyday life. ${ }^{2}$ While this is based on only one out of several possible ways to explicate the vernacular, it will be a useful starting point for introducing salient features of the Tibetan linguistic sphere, and of presently entertained controversial debates. In a Tibetan context, the locally spoken language has with very few exceptions not become a medium of literary composition of any kind. Across the sparsely populated Tibetan plateau and in those adjacent areas where ethnic Tibetans have settled, a large number of dialects are spoken, altogether around fifty. "Dialect" roughly translates Tibetan $y u l s k a d,{ }^{3}$ the language of a "place" or region. Linguists have come to name these dialects, which are not always mutually intelligible, according to the regional identification that speakers themselves provide. Thus, the Amdo dialect is the language of the region of Amdo (a mdo skad) in eastern Tibet, the Khams dialect the language spoken in Khams (khams skad), the region to the south of Amdo (now respectively in the Qinghai and Sichuan provinces of

1 Thanks are due to, first of all, Stephan Müller, Norbert Kössinger, Pavlina Rychterová and Elke Krotz, who conceptualized and organized the 2013 Vienna conference where an earlier version of this paper was presented first. This paper, moreover, would not have been possible without many subsequent stimulating discussions with colleagues in the environment of the Cluster of Excellence "Asia and Europe in a Global Context" at the University of Heidelberg, and I would especially like to thank Jonathan Samuels (Geshe Sherab Gyatso) and Monica Juneja.

2 Cf. NiedZIELSKI, Nancy: "Vernacular", in: Encyclopedia of Language and Linguistics, vol. 13, Tor-Z (2006), p. 414-415 for a brief account of the shifting and varying uses of "vernacular" in different branches of linguistics.

3 Tibetan terms and names are transliterated according to the Extended Wylie Transliteration Scheme, as outlined on the website of the Tibetan Himalayan Library at the University of Virginia: http:// www.thlib.org/reference/transliteration/\#!essay=/thl/ewts (09.04.2016). One main exception is that the initial letter in personal and place names, as well as names of religious schools and orders, is capitalized by convention, to facilitate the identification of Tibetan names as such. Anglicized place names (e.g. "Amdo") are also used when available. As it is also explained further below, the Wylie transliteration is no indicator of pronunciation, since Tibetan orthography displays a remarkable stability and has not changed alongside with phonetic changes in the spoken language, hence the numerous silent pre-, sub-, super- and postscript letters that tend to puzzle the neophyte. Transcription according to phonetic systems such as the Simplified Phonetic Transcription of Standard Tibetan by the Tibetan Himalayan Library (http://www.thlib.org/reference/transliteration/\#!essay=/thl/ phonetics/ [09.04.2016]) may be easier to pronounce and remember, but such systems are always partial to the orthography and phonetics of a particular European language (usually English), and in practice they are rarely used consistently and systematically. 
the People's Republic of China). ${ }^{4}$ The distinction between dialect and language remains however problematic, ${ }^{5}$ and it is not consistently applied in research on the Tibetan linguistic spectrum. A variety of the language spoken around Lhasa has become a lingua franca that allows Tibetans in China as well as in the diaspora to speak a common language (spyi skad). From a linguistic point of view this common language can in its present state be considered a language in the process of standardization. ${ }^{6}$ Still, dialect usage prevails on the most common colloquial level, meaning that everyday language use is strongly localized. The colloquial language, commonly referred to as phal skad ("ordinary language"), is however rarely used for composing literature. Even more, it is generally not considered fit for the composition of literary works of any kind. The term phal skad is accordingly often used with a pejorative connotation: to say that an expression is phal skad is equivalent to saying that it does not deserve to be used in writing, that it falls short of a certain standard.

In the history of Tibetan literature, which by now extends over some 1300 years, very few authors wrote in the colloquial language of their community, although on occasion dialectal features and regionalisms have been traced in written texts. Some of the earliest treatises in the Buddhist Bka' gdams lineage from the late eleventh, early twelfth centuries for instance preserve lexemes from the 'Phan po dialect spoken to the northeast of Lhasa. ${ }^{7}$ More than six hundred years later, the scholar Gung thang dkon mchog bstan pa'i sgron me (1762-1823) from Amdo wrote quite consciously a few texts in his native dialect. ${ }^{8}$ The small number and marked nature of such cases suggests that the dismissive attitude towards local speech expressed in a little treatise by the early fifteenth century Dge lugs pa scholar-monk Mkhas grub rje $^{9}$ may well be representative, and in any case might have proven rather effective as a barrier against the literarization of the colloquial. In addition, well into the twentieteh century, access to education in Tibet primarily meant joining a monastery, even if only temporarily. Much of Tibetan literature consists in compositions by religious literati. The written language, generally referred to as yig skad, thus encompasses the important subcategory of chos skad, the language of the Dharma,

4 For empirical and theoretical problems of Tibetan dialect classification cf. SUN, Jackson T.-S.: Phonological Profile of Zhongu: A New Tibetan Dialect of Northern Sichuan, in: Language and Linguistics 4/4 (2003), p. 769-836, here p. 794-797 (especially pointing out problems of Khams as a dialect unit), and HiLl 2010: $111 \mathrm{f}$.

5 Cf. Comrie, Bernard: Introduction, in: The World's Major Languages (Second Edition), ed. by Bernard Comrie, London/New York 2009, p. 1-22, here p. 2-4 for a general discussion of the distinction between language and dialect, especially of problems presented by "mutual intelligibility" as a distinguishing criterion.

6 Tournadre, Nicolas/Dorje, Sangda: Manual of Standard Tibetan. Language and Civilization, Ithaca, New York/Boulder, Colorado 2003, p. 25 f.

7 Eimer, Helmut: Rnam thar royas pa. Materialien zu einer Biographie des Atiśa (Dipaṃkaraśrijiñāna), Wiesbaden 1979, $95 \mathrm{ff}$.

8 Steinkellner, Ernst: - - rary Source for Late 18th Century Spoken Tibetan (Amdowa), in: Acta Orientalia Hungarica 34 (1980), p. 245-248.

9 VAN DER KUIJP, Leonard W. J.: Studies in the Life and Thought of Mkhas-Grub-Rje IV: MkhasGrub-Rje on Regionalisms and Dialects, in: Berliner Indologische Studien 2 (1986), p. 23-49. 
the Buddhist religion. If Tibetans nowadays also use "chos skad" to refer to the literary language in general, and not just to an idiom fit for the composition of literature on religious subjects, ${ }^{10}$ this only confirms the normative status of religious literature in Tibetan cultural perception at large.

Given the current state of research, the history of the written Tibetan language can be broadly divided into three stages. With "Old Tibetan" one usually refers to the language during the period from ca. $600 \mathrm{CE}$ onwards when an empire formed on the Tibetan plateau that gradually adopted Buddhism as a (though not necessarily the $)^{11}$ state religion. ${ }^{12}$ The ruling dynasty of Spu rgyal hailed from the Yarlung valley to the Southeast of present-day Lhasa, and Old Tibetan must have been based on the colloquial language of the Spu rgyal and their kin. The empire gradually expanded even beyond the plateau into all cardinal directions, making a particularly strong cultural impact in the Northeast - the oasis town of Dunhuang came under Tibetan control in 786 - and in Khams and Amdo. In the course of the expansion of this empire through (marriage) diplomacy and in military confrontation with Uighur and T'ang Chinese forces, the Tibetan writing system had become used for several languages spoken in the western part of the Tibetan plateau as well as in central Asia, including Chinese, as well as for languages that remain unidentified and are likely extinct. Zhang zhung, the language of an older empire in western Tibet and the sacred language of the Bon religion as it forms in the eleventh century, ${ }^{13}$ as well as other languages spoken in the territories that came under imperial rule, could not withstand the pressure of the expanding linguistic area of Old Tibetan, and died out (but might have left traces in Old Tibetan before doing so). After the disintegration of the empire around 850, and the end of Tibetan rule in central Asia, Old Tibetan continued to be used in that region as a lingua franca of high prestige through the eleventh century. In central and western Tibet, Old Tibetan was eventually replaced by Classical Tibetan, from which Old Tibetan is distinguished primarily by particular orthographic features.

10 See e.g. the controversy about whether Ladakhi should be written, as discussed in ZEISLER, Bettina: Why Ladakhi must not be written - being part of the great tradition: another kind of global thinking, in: Lesser-Known Languages of South Asia: Status and Policies, Case Studies and Applications of Information Technology, ed. by Anju Saxena/Lars Borin, Berlin/New York 2005, p. 175-191 (and below).

11 Scherrer-Schaub, Cristina: A Perusal of Early Tibetan Inscriptions in Light of the Buddhist World of the 7th to 9th Centuries A.D., in: Epigraphic Evidence in the Pre-Modern Buddhist World: Proceedings of the Eponymous Conference Held in Vienna, 14-15 Oct. 2011, ed. by Kurt Tropper (Wiener Studien zur Tibetologie und Buddhismuskunde 85), Wien 2014, p. 117-165, here p. 120, No. 10.

12 For the following cf. TAKeUChI, Tsuguhito: Formation and Transformation of Old Tibetan, in: Journal of Research Institute, Kobe City University of Foreign Studies 49 (2012), p. 3-17.

13 The term bon is in the West still often used to refer to a pre-Buddhist "native" religion of Tibet, but while certain priests involved in royal cults were called bon po, there is no evidence of an organized religion called bon prior to the advent of Buddhism. The connection between the (school of) religion which refers to itself as bon since the 11th century and pre-Buddhist beliefs is a matter of debate. See Kvaerne, Per: The Study of Bon in the West: Past, Present, and Future, in: New Horizons in Bon Studies (Bon Studies No 2), Osaka 2000, p. 7-20 for an outline of the problems involved. 
By "Classical Tibetan" - linguists prefer "Written Tibetan" - Tibetologists refer very broadly to the literary language that is in use since approximately the eleventh century. Modern Literary Tibetan is the language of newspapers and modern secular publications, of novels or short stories since 1949, when Tibet was incorporated into the People's Republic of China. It can be distinguished from Classical Tibetan chiefly in terms of vocabulary, but remains conservative in grammar. Modern Literary Tibetan includes a large number of loanwords from Chinese, whereas English and Hindi are the two main source languages for lexical borrowing in the Tibetan diaspora that has its cultural and political centres in the Republic of India. Classical Tibetan continues to be used as a literary language in religious circles.

The Tibetan literary language displays on the whole a high degree of stability and conservatism, to the extent that students who learn to read texts of the nineteenth century will generally be able to also read texts that were composed 700 years earlier, provided they familiarize themselves with the requisite vocabulary. The writing system can be regarded as the most visible sign of linguistic conservatism, as the Tibetan script is, save for relatively minor changes in orthography, the same today as it was in the imperial period. Compare below the image of a ninth century manuscript found in Dunhuang (PT 1288, Old Tibetan Annals) ${ }^{14}$ with a few lines from a twenty-first century book using Unicode-compliant fonts:

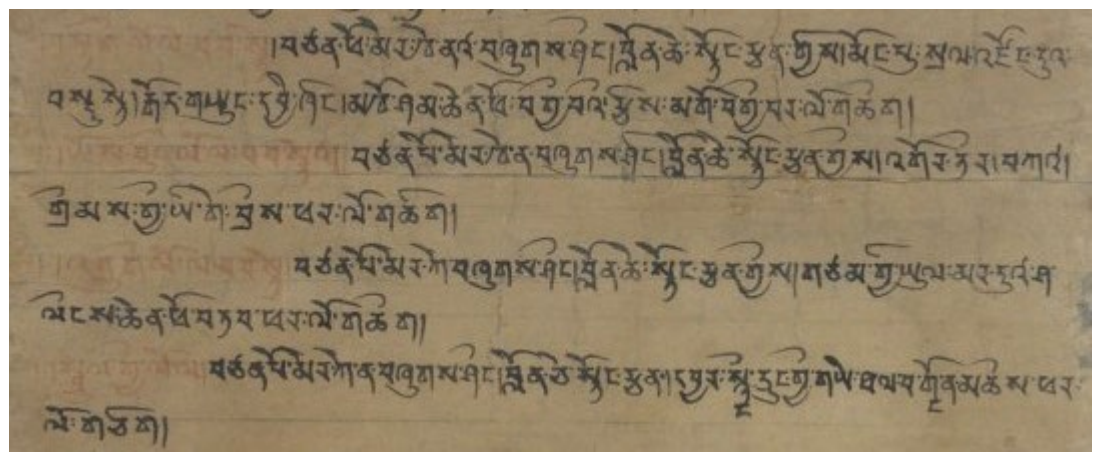

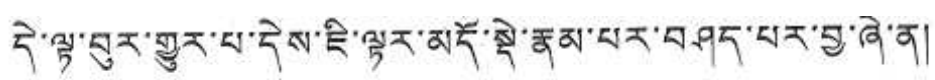

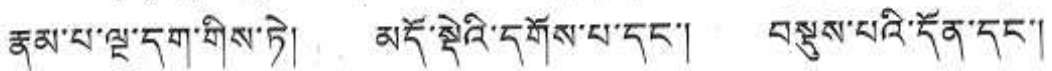

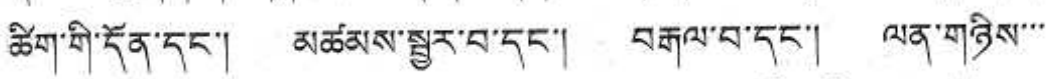

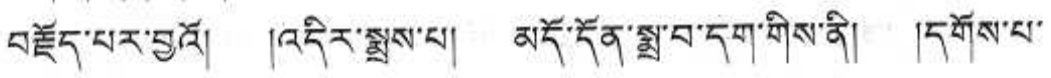

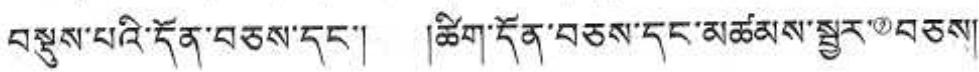

Given that the spoken language changed phonetically over time, Tibetan orthography is no longer an indicator of pronunciation. This overall linguistic conservatism

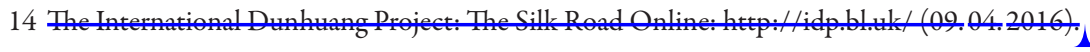


should not be taken to imply that the language remained completely unchanged over centuries, but research on historical changes and possible regional variations in the use of the written language is at present still in its infancy.

Unlike modern linguists, many Tibetans think that the colloquial language does not even have a true grammar. Attempts to grammaticalize Tibeto-Burmese dialects and to stabilize them in writing are a relatively recent phenomenon. The Bhutanese government introduced a new orthography of Dzongkha, the official language of Bhutan. In Ladakh Christian missionaries strove to introduce an orthographic reform to write Ladakhi, and to begin school instruction in the vernacular. The discrepancy between spoken and written language added to the motivation for reform initiatives, for precisely because Tibetan orthography is no longer in sync with a spoken language, even monks often have difficulties writing. ${ }^{15}$ Reforms, however, met with resistance on the part of Buddhist scholar-monks, who continue to be viewed as cultural authorities in their communities. Although such resistance on the one hand reflects attempts to preserve a traditional status of authority in the face of social change, it also has to be seen in in larger context of Tibetan identity politics. The Chinese language has become the dominant linguistic medium on the Tibetan plateau, next to which Tibetan enjoys an uncertain status. The Classical Tibetan idiom and the great Buddhist religious tradition have become regarded (and promoted) as defining features of Tibetan cultural identity across national and geographic boundaries, serving as a unifying feature for communities spread across several states, territories, and even continents. The literarization of the colloquial language is in this context perceived as yet another threat to the unity of Tibetan culture. Such an assessment was already given by the tenth Panchen Lama in his famous "Poisoned Arrow" petition of 1962, a secret document (issued in Mandarin) that offers a devastating critique of the Chinese Tibet policy between 1919 and 1962 (and became public only in 1996). ${ }^{16}$ Interestingly, the unconventional scholar-monk Dge 'dun chos 'phel (1903?-1951) - perhaps the only Tibetan of his times to journey extensively through colonial India - had already expressed a similar view in the late 1940s. Dge 'dun chos 'phel praised the stability in form of the Tibetan writing system, especially in view of the great disparity between historical Indian scripts and the present-day form of Indian letters. Highlighting the unifying function of the written idiom that enables communication among literate persons from Mnga' ris in the west to Amdo in the east, he further warned that a literarization of colloquial languages such as Ladakhi would lead to "further debilitation of racial and political integration." ${ }^{17}$

15 See ZeISLER 2005 [Anm. 10] for an account of Ladakhi controversies.

16 Panchen Lama: A Poisoned Arrow: The Secret Report of the 10th Panchen Lama. The full text of the Panchen Lama's 70,000 Character Petition of 1962, together with a selection of supporting historical documents (Tibet Information Network Background Briefing Paper 29) London 1997, p. 68f.

17 Translation see Zeisler 2005 [Anm. 10], p. 181. The passage is found in Dge 'dun chos 'phel's White Annals (deb ther dkarpo). 


\section{Historical Beginnings: How Tibetan became a Literary Language}

The above foray into contemporary debates surrounding the literarization and grammaticalization of Tibetan vernaculars such as Ladakhi underscores the point that vernacular literary languages do not simply "emerge" - vernacularization is the making of a new literary culture, the result of a cultural choice that needs to be understood in a social and political context, and properly historicized. This point was forcefully made by Sheldon Pollock, whose wide-ranging studies of vernacularization across South and Southeast Asia offer much food for thought and will be drawn upon repeatedly in the following ${ }^{18}$ - although selectively, and not without in the final section of this paper pointing to problems raised by an extension of Pollock's theorization of the vernacular to Tibet.

Based on his studies of how vernacular literary cultures are being made within the sphere of the "Sanskrit cosmopolis", starting with 1000 and accelerating mostly around $1500 \mathrm{CE}$, Pollock defines vernacularization more sharply as

\footnotetext{
"the historical process of choosing to create a written literature, along with its complement, a political discourse, in local languages according to models supplied by a superordinate, usually cosmopolitan, literary culture." 19
}

In other words, the cultural choice that drives vernacularization takes place in a situation where a preexisting literary culture that is "superordinate" or "superposed" provides particular models. These might then be treated in different ways, as vernacular literati might emulate, selectively adopt or even reject them, but in any case these models are confronted. For Pollock, moreover, the use of vernaculars as literary languages instead of the cosmopolitan that had enjoyed the privilege of being used for literature has to be authorized. This, too, is confirmed by present-day controversies in the Tibetan linguistic sphere.

The written Tibetan language (Old and Classical Tibetan) has enjoyed the status of a cosmopolitan language for a long time. This is obviously true if by cosmopolitan languages we refer to a common, standardized and translocal language used by geographically dispersed communities whose colloquial languages and dialects differ considerably from one another - a language used especially for the purpose of written communication and documentation, and even more especially for literary purposes, for anything that extends beyond the realm of mere record-keeping. Written Tibetan is a language. Its cosmopolitan character is further in evidence in its historical use by non-Tibetan speaking communities as a lingua

\footnotetext{
18 Pollock, Sheldon: The Sanskrit Cosmopolis, 300-1300: Transculturation, Vernacularization, and the Question of Ideology, in: Ideology and Status of Sanskrit: Contributions to the History of the Sanskrit Language, ed. by Jan E. M. Houben, Leiden 1996, p. 197-247; Pollock, Sheldon: The Cosmopolitan Vernacular, in: Journal of Asian Studies 57 (1998), p. 6-37; Pollock, Sheldon: Cosmopolitan and Vernacular in History, in: Public Culture 12/3 (2000), p. 591-625; and especially PolLOCK, Sheldon: The Language of the Gods in the World of Men. Sanskrit, Culture and Power in Premodern India, Berkeley 2006.

19 Pollock 2006 [Anm. 18], p. 23.
} 
franca in central Asia after the fall of the empire, as well as, later, as a koiné among Mongols and Manchus, and as a (Buddhist) church and high literary language in Buryatya and Kalmykia. Traces of this status linger on until today, even after historical and political ruptures in the respective regions. With the revival of Buddhism after the fall of the Soviet empire Tibetan became again a required subject in public schools in Astrakhan. ${ }^{20}$

Most cosmopolitan languages were at some point in their history vernaculars, and hence changed their status over time. Considering the remarkable stability and conservatism of written Tibetan in the longue durée, exploring the historical beginnings of Tibetan literacy, and the processes that turned Tibetan from a vernacular to a cosmopolitan language, means to step back rather far in history, into the period of empire.

\subsection{The Formation of the Tibetan Writing System and Origin Stories of Writing}

It was, again, Pollock who observed that, across South and Southeast Asia and across Europe, the process of vernacularization frequently occurs in two stages. The first stage is literization or Verschriftlichung of the vernacular language, the beginnings of the use of writing for a language. The second stage, which may be separated from the first by a long interval, perhaps even centuries, is literarization, the beginnings of a language's use for expressive purposes. ${ }^{21}$ Across South and Southeast Asia, the sphere that Pollock refers to as the "Sanskrit cosmopolis", vernacular languages are at first written for some time for purely documentary purposes. The vernaculars are languages of record-keeping, of the informative and constative realm, of keeping track of land grants and property proceedings. This in itself is remarkable in macrohistorical comparison, considering that in the Latin world of medieval Europe, vernaculars such as French or German were denied the right to record. Lacking the kind of stabilization by grammar that distinguished Latin, they were viewed as unstable, as unfit for expressing lasting truths. ${ }^{22}$ Across the Sanskrit cosmopolis, on the other hand, the local language is used to document the world and, at first, only to document it, not to interpret it. Its textualization for expressive, aesthetic ends - for "workly" tasks, in Pollock's adaptation of Heidegger's werkhaft ${ }^{23}$ - comes later according to models provided by a superposed Sanskritic literary culture. The superposed cosmopolitan language, which enjoyed privileged use in the expressive realm, is supplemented and eventually supplanted by the vernacular. Typically, the textualization of the vernacular is accompanied by the

20 Kapstein, Matthew: The Indian Literary Identity in Tibet, in: Literary Cultures in History: Reconstructions from South Asia, ed. by Sheldon Pollock, Berkeley/Los Angeles/London 2003, p. 747-802, here p. 751 (relying on Nicolas Tournadre).

21 Pollock 2006 [Anm. 18], p. 298, p. 605.

22 Ibid., p. 509.

23 Ibid., p. 3. 
philologization of the vernacular, ${ }^{24}$ the creation of grammars, dictionaries, or prosody manuals. 25

For Tibetan, we may similarly observe that the beginnings of the written language are connected with documentary tasks, with administration; this is also how the creation of a script is presented in the sources that in time to the actual process. Surrounded by literate cultures in central Asia, China, Kashmir and Nepal, Tibetans might have been exposed to different scripts and languages for considerable time. Still, the construction of a distinctive writing system for the Tibetan language, based on Indian models, was for all we know only undertaken in the course of the first half of the seventh century CE when the rulers from Yarlung began to expand their rule across the plateau, and diplomatic contacts and military confrontations with neighbouring polities become apparent in the historical record. From a palaeographical point of view, the Tibetan script, alphasyllabic in type, was most probably modelled after writing systems that are attested in Northern India and Nepal in the seventh century. Sam van Schaik recently argued that the most credible model - which Tibetans did not copy, but adapted selectively - is an early seventh-century inscriptional style of the Siddhamātrikā script. ${ }^{26}$

The oldest known references to the use of writing in Tibet already testify to the cultural contacts brought about by empire formation, for these are actually passages in the Chinese Old Tang Annals (Jiu Tangshu), although these are not (yet) unambiguous references to the use of a special writing system coined for the Tibetan language. In 634, the Tibetan emperor (btsan po) Srong btsan sgam po (c. 605-649) sent envoys to the Chinese emperor and subsequently despatched a respectful letter petitioning for a matrimonial alliance. Such a letter would, however, probably have been written in Chinese, and likely not by the emperor himself. In 648, Srong btsan sgam po is said to have applied to the Chinese emperor for workmen to manufacture paper and ink or brushes. ${ }^{27}$ The Old Tibetan Annals, ${ }^{28}$ likely the oldest

24 Ibid., p. 283, p. 592.

25 POLLOCK 1998 [Anm. 18], p. 8.

26 van Schaik, Sam: A New Look at the Source of the Tibetan Script, in: New Studies of the Old Tibetan Documents: Philology, History, and Religion, ed. by Yoshiro Imaeda/Matthew Kapstein/ Tsuguhito Takeuchi (Old Tibetan Documents Online Monograph Series III), Tokyo 2011, p. 45-96, here p. 69-72. Van Schaik's article is the most recent in a long series of attempts by (Tibetan as well as Western) scholars to resolve the puzzle of the origin and creation of the Tibetan writing system, which are also helpfully reviewed in connection with his new proposal.

27 LAUfer, Berthold: Origin of Tibetan Writing, in: Journal of the American Oriental Society 38 (1918), p. 34; translation in BushelL, S. W.: The Early History of Tibet. From Chinese Sources, in: Journal of the Royal Asiatic Society of Great Britain and Ireland, New Series, Vol. 12, No 4 (Oct. 1880), p. 446, and LeE, Don Y: The History of Early Relations between China and Tibet: from Chiu t’ang-shu, a documentary survey, Bloomington, Indiana 1981, p. 13.

28 The work referred to by this English title is preserved in two fragmentary versions (see Dotson, Brandon: The Old Tibetan Annals: An Annotated Translation of Tibet's First History [Veröffentlichungen zur Sozialanthropologie 12], Wien 2009, p. 14). The manuscripts found in Dunhuang date to a later period, but stylistic and orthographic considerations show that these brief and laconic records must have been written close to the date of the events they report, possibly initially on wooden slips (Ibid., p. 11, No 6), and were later copied to paper. 
extant composition in the Tibetan language ${ }^{29}$ and in style possibly influenced by Chinese annalistic practices, record for 654 that chief minister (Mgar) Stong rtsan (yul zung) made the manuals for the execution of the great administration ( $m k h o$ sham chen pho bgyI ba'I rtsis mgo bgyI bar... ). In 655, the chief minister wrote the texts of the law at 'Gor ti (blon che stong rtsan gyIs / 'gor tIr / bka' / grIms gyI yi ge brIs phar ... ). ${ }^{30}$ The degree of administrative sophistication that is suggested by these documents would have taken some time to achieve. It is difficult to imagine how it could have been accomplished only with knotted strings or notched pieces of wood, which the Old Tang Annals say were used in Tibet prior to the introduction of writing. ${ }^{31}$ While structured and formalized orality may accomplish far more than our own thoroughly literized cultural perspective is ready to grant, it is also extremely improbable that Tibetan versified songs $(g l u)$ that apparently were also used to record administrative practice would in themselves have been sufficient to regulate an expanding empire. ${ }^{32}$ Writing, in short, must already have been in use for some time, possibly even prior to the reign of emperor Srong btsan sgam po. ${ }^{33}$ The oldest preserved specimens of Tibetan writing today are royal edicts mainly on stone pillars, dating back as far as the mid-eighth century. ${ }^{34}$ Manuscripts of Old Tibetan documents were found in hiding places or in sacred deposits of central Asia, in Mirān and the erstwhile Tibetan fort-site Mazār Tāgh, and, most prominently, in the so-called "library cave" of Dunhuang (cave 17). These, however, present considerable difficulties for dating. While, for example, the documents in cave 17 were initially thought to have been written during the Tibetan occupation of Dunhuang (786-848), scholars have determined that a large number of them were actually written after the fall of the empire, prior to the sealing off of the cave in the first half of the eleventh century. ${ }^{35}$ At the same time, (older) documents from central Tibet were brought there, as can in some cases be determined from miscro-

29 Ibid., p. 14 and p. 74.

30 PT 1288,26-29, text and translation Dotson 2006, p. 25; cf. Dotson 2009 [Anm. 28], p. 54, No 76 and van Schaik 2011 [Anm. 26], p. 53, No 27 for the difficult term rtsis mgo). Chinese sources mention that minister Stong rtsan/btsan was illiterate, but this may well mean that he used an Indian-derived writing system unknown to the Chinese and was hence illiterate in their writing system (ZeIsLer, Bettina: On the Position of Ladakhi and Balti in the Tibetan Language Family, in: Ladakhi Histories: Local and Regional Perspectives, ed. by John Bray (Brill's Tibetan Studies Library 9), Leiden 2005, p. 41-64.

31 Translation in Bushell 1880 [Anm. 27], p. 440, and LeE 1981 [Anm. 27], p. 3. The purpose of using strings and carving pieces of wood is there expressly given as fixing agreements (by oath).

32 For these songs cf. Ellingson, Terry Jay: The Mandala of Sound: Concepts and Sound Structures in Tibetan Ritual Music, Madison, Wisconsin 1979 (PhD Dissertation), p. 67-70, as well as below.

33 For a stronger version of this argument cf. ZeISLER 2005 [Anm. 30], p. 46.

34 The most recent comprehensive documentation of inscriptions is IwaO, Kazushi/Hill, Nathan/ Takeuchi, Tsuguhito: Old Tibetan Inscriptions (Old Tibetan Documents Online Monograph Series II), Tokyo 2009, in many ways updating the "classical" editions and studies of RICHARDSON, Hugh E.: A Corpus of Early Tibetan Inscriptions, London 1985 and LI, Fang Kuei/CoBlin, Weldon South: A study of the old Tibetan inscriptions, Taipei 1987.

35 Dotson, Brandon/Helman-Ważny, Agnieszka: Codicology, Paleography, and Orthography of Early Tibetan Documents: Methods and a Case-Study (Wiener Studien zur Tibetologie und Buddhismuskunde 88), Wien 2016, p. 18 f. 
scopic analysis of paper fibers. ${ }^{36}$ Dating and localizing Old Tibetan literature is, in any case, a complicated matter.

While the historical record nonetheless shows that writing first appears for documentary purposes, the historical memory created and perpetuated since the late imperial period places the creation of the writing system in a chiefly religious context, to some degree also a diplomatic one.

To understand the mechanisms at work, a brief outline of general history will be helpful. The introduction of Buddhism in Tibet was a haphazard undertaking at first, and its establishment a slow process against the resistance of priests of older royal cults (also known as Bon) and their supporters among nobility, with occasionally wavering commitment by emperors. As emperor Khri srong lde btsan (r. 755-794) and his successors made the commitment of the state to Buddhism explicit beginning in the second half of the eighth century, through the construction of monasteries and temples and the provision of substantial material resources to nascent monastic communities, royal edicts promulgated that (ahistorically) taim emperors of the past as fervent supporters of the religion and even as embodiments of the chief salvific figure of Mahāyāna Buddhism, the bodhisattva. Historical memory, in short, to be "buddhicized". The glorification of emperors and ministers as heroic figures pursuing the mission to civilize the wild Tibetan people through Buddhism even more prominent in historical myths that formed after the disintegration of the empire around 850 . On the Tibetan plateau, the following approximately hundred years a period of political turmoil, social instability and cultural loss, referred to by Tibetan historians as "period of fragments" (bod sil bu). Few, if any, written documents survive from this time. By the late tenth century, local rulers from western and later also central Tibet contacts with neighbouring Indian regions and, claiming continuity with the imperial dynasty, in a revival of Buddhism. This the period of religio-cultural efflorescence - some speak of the Tibetan Buddhist renaissance - that historians then call the "later dissemination of the doctrine" (bstan pa phyi dar) that well into the fourteenth century, thereby distinguishing it from the "early dissemination" (snga dar) more or less coterminous with the period of empire.

As for the introduction of writing, the Old Tibetan Chronicle (PT 1286+1287), an epic history of the great deeds of kings and ministers in the imperial period definitively dating to before the eleventh century and perhaps even our earliest account of this time, presents writing in connection with documentary tasks and the running of a state. Writing did not exist before the rule of Srong btsan sgam po, and its introduction is related to this ruler's establishing the "entire good basis of Tibet's customs" (bod kyi chos kyi gzhung bzang po kun): the legal system, the establishment of ranks in government, the division of lands, and the standardization of weights and measures. ${ }^{37}$ No explicit reference to Buddhism is made here, in stark contrast to the $D b a^{\prime} b z h e d$, a "royal narrative concerning the bringing of the

36 For pioneering studies of this kind, see Dotson/Helman-Ważny 2016.

37 PT 1287,446-555 (translation and discussion in Dotson 2006 [Anm. 30], p. 12f.). 
Buddha's doctrine to Tibet" (bka-mchid kyi yi ge) recorded by Gsal snang of the Dba'-clan (hence the title) that maycontain parts from the ninth or tenth century. ${ }^{38}$ During Srong btsan sgam po's reign, a young man called Thon mi gsam po ra (later more commonly: Thon mi sambhota $)^{39}$ is sent to India to retrieve the Buddhist doctrine and a model for an alphabet. He returns in the company of Li byin, a learned Indian, and brings back the Ratnameghasütra as well as other Buddhist texts. These texts receive the royal seal and are placed in the treasury of Phying pa [ a marginal note in the manuscript explains that they were placed there because noone could translate them. Four attendants in charge of royal household affairs are taught the alphabet (whose formation is not discussed). The emperor enters a retreat, and the subjects begin to wonder whether ministers rule instead. The emperor consults the four literate attendants and within four months makes the law on the basis of the ten Buddhist virtues ( $b k a^{\prime} k h r i m s$ ) and puts it in writing. Srong btsan sgam po leaves the palace and proclaims the law to the people, who offer thanks and praise him for being wise (sgam po) - note the pious buddhicized account of the emperor's name, which the Chronicle by contrast derives from the his exchange of victory songs with the chief minister, after battle. Srong btsan sgam po then orders that Thon mi and Li byin teach the letters to all people. From then on, the alphabet is present in Tibet. At some point after these events letters are being sent to the Chinese emperor, who then grants a bride - a properly Tibetan alphabet, in other words, is also a prerequisite for diplomatic exchange.

The narratives surrounding Thon mi are further elaborated and embellished throughout historiographical literature of the late-dissemination period; variation is plentiful. It is worth stressing that like many other writing systems, the Tibetan script comes to be attributed to the genius of one single inventor. This inventor is a cultural mediator, and even elevated to the status of the cultural mediator par excellence required for the Buddhification of Tibet, the lotsāva, the master-translator, for Thon $\mathrm{mi}$ is also eventually credited with retrieving and translating several Buddhist sütras, though no translations under his name are preserved. ${ }^{40}$ From the varying accounts of his pursuits, Thon mi further emerges as the foremost linguistic expert. He is credited with the authorship of two foundational grammatical treatises of the Tibetan language, the Sum cu pa and the Rtags kyi 'jug pa - two ellipitic texts modelled on Sanskritic grammatical traditions, which later inspired a rich commentarial tradition in Tibet. Already for the relatively simple account of the $D b a^{\prime} b z h e d$ summarized above, the historicity of many aspects can be reasonably

38 The text edited and translated in WANGDU/Diemberger 2000 in their view dates to the 11th century at the earliest. Manuscript fragments were found in Dunhuang, dateable to the 9th or 10th century (van SchaIK, Sam/IWAO, Kazushi: Fragments of the Testament of Ba from Dunhuang, in: Journal of the American Oriental Society 128.3 (2008), p. 477-487). The passage dealing with the introduction of writing is translated on p. 26-30.

39 See Sørensen, Per K.: Tibetan Buddhist Historiography: The Mirror Illuminating the Royal Genealogies, Wiesbaden 1994, p. 167f., No 462, for different versions of his name given in various historical sources.

40 See SKILLING 1997, p. 87-89 for the translations attributed to him. 
called into question, not the least the creation of a Buddhist law code by Srong btsan sgam po or any of his followers. ${ }^{41}$ The existence of a minister called Thon mi is not positively supported by the Old Tibetan Annals, or by any other source prior to the (late tenth century) Dba'bzhed. On the other hand, elements of the various forms of the narrative have credible historical significance in the imperial period, even though their connection with Thon mi must be regarded as doubtful. For instance, the Ratnameghasutra that Thon mi reportedly retrieved from India appears to have played an important role in the transmission of Indian Buddhist notions of the king as a salfivic figure, a bodhisattva, to China, central Asian kingdoms and probably also to Tibet. The translation of this sütra, moreover, occasioned the earliest authoritative decision by the Tibetan emperor for regulating translation processes at large. ${ }^{42}$

\subsection{Translation and the "Literarization" of the Tibetan Language}

Let us note, now, what the Thon mi narrative is not. It does not account for the origin of the Tibetan language, or of a distinctively Tibetan literature. The main activities in the literary realm that clerical historians from the eleventh century onwards regard as worthy of memorializing are the retrieval of Buddhist texts from India, and their translation into Tibetan, all under the overarching theme of establishing the Dharma in the Land of Snow. The establishment of Buddhism also constitutes the primary context for the earliest philologization of the Tibetan language, and, arguably, for the literarization of the Tibetan language. Soon after emperor Khri srong lde btsan declared Buddhism a state religion, the court regarded it as necessary to intervene in translation processes which were gradually being organized in a more rigorous fashion. This is evident in a series of decrees issued by Khri srong lde btsan and his son and successor, Khri lde srong btsan, contained above all in the Sgra sbyor bam po gnyis pa, "On the Use of Words in Two Volumes". ${ }^{43}$ These decrees reveal how translation was increasingly placed under state control, organized in colleges that had to submit to the emperor as supreme authority. Committees of high

41 As demonstrated in Richardson, Hugh E.: Early Tibetan Law Concerning Dog-Bite, in: Bulletin of Tibetology 3 (1989), p. 5-10, imperial Tibetan law is a detailed codification of precedent and takes the social status of victims and perpetrators in a highly stratified society into consideration. Punitive measures are harsh, and not consistent with Buddhist injunctions against the taking of life.

42 Scherrer-Schaub 2002, p. 298-304, also for the importance of the Ratnameghasuttra translation in the compilation of glossaries. For China, see the classical study of ForTe, Antonino: Political Propaganda and Ideology in China at the End of the Seventh Century, Napoli 1976.

43 Fragments of a shorter (older) version were found in the western Tibetan monastery of Tabo (see PANGLUnG, Jampa: New Fragments of the sGra-sbyor bam-po gñis-pa, in: East and West 44/1 (1994), p. 161-172), while the version in the treatises section of the Tibetan Buddhist canon, the Bstan 'gyur is more elaborate (Simonsson, Nils: Indo-tibetische Studien. Die Methoden der tibetischen Übersetzer, untersucht im Hinblick auf die Bedeutung ihrer Übersetzungen für die Sanskritphilologie, Uppsala 1957; IsHIKAWA, Mie: A Critical Edition of the Sgra sbyor bampo pa: An Old and Basic Commentary on the Mahävyutpatti [Studia Tibetica 18], Tokyo 1990). For a neticulous study of the Use of Words as a charter see SCHERRER-SCHAUb 2002 [Anm. 42]. 
ecclesiastical authority were to rule on newly proposed translation terminology. The decrees reflect the extraordinary importance that the rulers of Tibet accorded to a correct transmission of the Dharma. According to the second of altogether three decrees contained in the Use of Words' introduction, translation became a problem because the Dharma language or chos kyi skad had not yet been widely known in Tibet. As a result, terms had come into use which did not agree with the Dharma treatises (chos kyi gzhung), and with the methods of Indian grammar (vyā ka ra na'i lugs). To resolve these problems, a revision was carried out: earlier terminological repositories were enhanced and terminology was brought to agree with "Hīnayāna and Mahāyāna treatises as explained by the earlier preceptors Nāgārjuna, Vasubandhu and others." In addition, terminology was harmonized to accord with analytical methods of Sanskrit grammatical analysis (vyākarana). ${ }^{44}$ Subsequent to the ratification of the results in the presence of the emperor and ministers, a royal decree was issued on the method of translating, prescribing the following general principle:

dam pa'i chos bsgyur ba'i lugs ni don dang / myi 'gal la bod skad la bde bar bya ba dang / rgya gar skad go rims las myi bsnor bar / don dang tshig tu' breld bar byos la sgyurd cig ${ }^{45}$

"As for the method of translating the Noble Dharma, translate so as not to contradict the meaning, to the advantage of the Tibetan language, without deviating from the word-order of the Indian language, and so that word and meaning are (well) connected."

To this rule from the older Tabo version of the Use of Words, the later canonized version adds exceptions that allow a modification of word-order within limits if "good language" consisting in the connection of word and meaning can otherwise not be obtained. ${ }^{46}$ As noted by Panglung, these additions likely reflect the increase in experience with translation, which had made the more general rule impractical. They also show that the process of translation was carefully monitored. A lexicographical commentary with 412 entries (in the canonized version) spells out the rationale for translating individual terms, appealing to analytical models from Sanskrit grammar and Indian Buddhist exegesis in the justification of translational choices. Against the specific nature of Indian-based explanations in these entries, the generic appeal to "good Tibetan" as a standard that is also to be upheld in translation remains remarkably undifferentiated. Indian philological and exegetical standards are clearly superordinate.

Considering that Tibetans were entangled with a multiplicity of cultures in neighbouring and further regions, and exposed to Buddhist traditions in a variety of languages including Chinese or Khotanese, it is worth noting that the Use of Words tackles translation from the Sanskrit as the default scenario, without paying attention to other source languages. By contrast, Tibetan translations of Ch'an

44 Simonsson 1957 [Anm. 43], p. 243 [sections 4 and 5] = IshiKaWA 1990 [Anm. 43], 1,35-2,10.

45 Text of the Tabo version, see PAnglung 1994 [Anm. 43].

46 Simonsson 1957 [Anm. 43], p. 248f. [sections 11 and 12] = IsHikawa 1990 [Anm. 43], 2,26-33. 
texts from Chinese found in Dunhuang reveal a different terminological register a "Chinese vocabulary" -, although there is overlap with the "Indian vocabulary" codified in the Use of Words, and there is also variation in translation practice. ${ }^{47}$ But translation from the Chinese was never regulated on the same level as translation from the Sanskrit. While the Use of Words does not expressly prohibit translation from non-Indian languages, the exclusive reference to Sanskrit in an authoritative royal decree is surely indicative of a cultural choice. This choice is in line with a doctrinal choice made by Khri srong lde btsan: following upon controversial exchanges between Indian and Chinese Buddhist masters - exchanges that sources from the $D b a^{\prime} b z h e d$ onwards crystallize into a single debate at Bsam yas monastery - , the emperor decided to limit his support to Indian Buddhism as a state religion. Chinese masters left, or according to some accounts were even expelled. ${ }^{48} \mathrm{~A}$ stronger orientation towards Indian Buddhism is clearly visible in the philological apparatus consisting in the Use of Words, as well as bilingual glossaries, notably the Mahavyutpatti, of which the Use of Words is a commentary. After the promulgation of the Use of Words, a great revision of extant translations followed, which effectively effaced older translations (much to our chagrin). Two catalogues of palace libraries not only offer insights into the spectrum of Buddhist literature that was translated at the time (including some translations from the Chinese), but also already list Tibetans as authors of commentaries and summaries on doctrine and ritual, of supplications and prayers, and of works in a question-and-answer style on doctrinal issues that point to a nascent polemical culture. ${ }^{49}$ In sum, approximately 200 years after the creation of a Tibetan writing system, a process of "philologization" of the written Tibetan language is set in motion that is entirely premised on translation and strongly relies on models and standards provided by a superposed Indian Buddhist culture.

In relation to this regulatory enterprise, Old Tibetan documents found in central Asia offer glimpses into a more variegated literary production, even though, as mentioned above, these documents are notoriously difficult to date and localize.

47 Stein, Rolf A.: Tibetica Antiqua I: The Two Vocabularies of Indo-Tibetan and Sino-Tibetan Translations in the Dunhuang Manuscripts, in: Rolf Stein's Tibetica Antiqua, with additional materials, translated and edited by Arthur P. McKeown, Leiden/Boston 2010, p. 1-96. Originally published in French as: Tibetica Antiqua I: Les deux vocabulaires des traductions indo-tibétaines et sino-tibétaines dans les manuscrits Touen-Houang, in: Bulletin de l'École Française d'Extrême-Orient LXXII (1983), p. 149-236.

48 Tibetologists debate whether there really was a debate at Bsam yas presided over by the emperor, with Kamalaśila and Hva-shang Mahāyāna as leaders respectively of the Indian and Chinese parties. Although the form of confrontation might not have been that of a single formal debate, an integrated reading of the divergent accounts in Tibetan and Chinese sources points to some form of controversy followed by an authoritative decision by the emperor. Kollmar-Paulenz, Karenina: The Buddhist Way into Tibet, in: The Spread of Buddhism, ed. by Anne Heirman/Stephan Peter Bumbacher, Leiden 2007, p. 323-325 offers a useful entry into the protracted scholarly debates (!) on the matter.

49 Halkias, Georgios: Tibetan Buddhism Registered: A Catalogue From the Imperial Court of 'Phang Thang, in: The Eastern Buddhist 35/1-2 (2004), p. 68. The earlier Ldan kar ma catalogue lists seven works of Tibetan authorship, while the later catalogue of 'Phang thang lists 126. A third catalogue, known as Dkar chags bsam yas mchims phu ma, is unidentified. 
To recapitulate, texts believed to date to before the fall of Dunhuang have now been convincingly dated to the post-dynastic period, when Tibetan was still used in the area as a lingua franca until the eleventh century; it is therefore difficult to tell whether departures from the regulations of the Use of Words reflect an earlier state or simply show that the regulations were not slavishly followed. Moreover, manuscripts found in Dunhuang and other sites could also have been brought there from central Tibet, as was the case with the Old Tibetan Annals, ${ }^{50}$ so that texts found in Dunhuang do not necessarily represent a literary production that was typical for central Asia and was able to flourish in greater geographical distance from the influence sphere of the court and its regulations. Still, Old Tibetan documents on the whole show an active and diversified engagement with a variety of literary styles and themes from other cultures. Translation activities focused on religious literature, but were not confined to Buddhist sources, and included works of a non-religious nature, as well. Chinese classics such as the Shangshu/Shujing, the Zhanguoce and the Shiji were translated into Tibetan. ${ }^{51}$ Fragments of a Tibetan version of the great Indian epic Ramanyana show clear signs of deliberate adaptation, and use themes and forms unparallelled in Indian versions. ${ }^{52}$ Versified songs (glu/mgur) are widespread, extolling the singer's or his group's exploits or provoking sung verbal combat. Songs also served to record administrative policy, right down to keeping census records of military governing districts. ${ }^{53}$ Some of the distinctive aesthetic and stylistic features of these versified songs are also found in the Old Tibetan Chronicle, a composition that therefore arguably defies neat classification as either "documentary" or "expressive". The Chronicle, lastly, also echoes motifs from the Indian epic and the Tibetan adaptation of the Rämãyana. ${ }^{54}$ It was also suggested that Chinese bianwen ("transformation") texts, popular, mostly versified popular stories on Buddhist saints or martial heroes, impacted Tibetan literature, and did so well beyond the imperial period. ${ }^{55}$ In short, we can safely say that early Tibetan-language writers emulated various literary codes, elaborated upon them, and also contributed their own.

2. Conclusion: Apropos the Sanskrit Cosmopolis

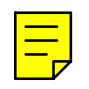

50 Dotson 2009 [Anm. 28], p. 10.

51 VAN DER KUijp, Leonard W. J.: Tibetan Belles-Lettres: the Influence of Dandin and Kșemendra, in: Tibetan Literature: Studies in Genre. Essays in Honor of Geshe Lhundup Sopa, ed. by José Ignacio Cabezón/Roger R. Jackson, Ithaca, New York 1996, p. 394.

52 DE Jong, Jan Willem: The Story of Rāma in Tibet: Text and Translation of the Tun-huang Manuscripts, Wiesbaden 1989. Cf. van DER KuIJP 1996 [Anm. 51] for traces of themes from the Rämäyaña in later Tibetan literature.

53 Ellingson 1979 [Anm. 32], p. 67-70.

54 Dotson, Brandon: Theorising the King: Implicit and Explicit sources for the study of Tibetan Sacred Kingship, in: Revue d'Etudes Tibétaines 21 (2011), p. 90-91.

55 KapsteIn, Matthew: The Tibetans, Malden/Oxford/Carlton 2006, p. 249-252. 
A closer look at the beginnings of literacy and literature in the Tibetan language shows that the three main elements of Sheldon Pollock's theorization of the Sanskrit Cosmopolis indeed provide a useful heuristic for approaching the subject. To recall, these elements are: literization as the introduction of writing, literarization as the making of a vernacular literature, and cultural superposition, accentuating the phenomenon that vernacular literature is made in engagement with a superposed, superordinate cosmopolitan cultural formation. In the imperial period in Tibet, one can indeed detect that literarization sets in only after literization - not unlike the processes giving rise to vernacular literacy across Asia and Europe that Pollock has surveyed. Writing is at first used for documentary purposes, and only later for expressive forms of literature. Old Tibetan documents strongly suggest that Tibetans began to use their language for purposes other than administration, record-keeping and legislation only once literary models deriving from Chinese or Indian contexts had entered their cultural horizon (perhaps primarily in the Dunhuang area), and emulation and adaptation of foreign (superposed) models primed literary activity in the Tibetan language. It may at first sight appear odd to regard processes such as large-scale translations of foreign religious literature and state-sanctioned interventions to organize these processes as symptomatic for the beginnings of Tibetan literature - but only if one conceives of the rise of vernacular literacy in terms of bound cultural entities that organically produce literature similar to the growth of plants from the soil. The beginnings of Tibetan literacy and (later) literature in the Tibetan language occur in an environment of intense cultural contact and exchange, and it is only reasonable to connect the rise of literature in the vernacular language with dynamics issuing from that environment.

To be sure, the regulatory intervention into textual practices evident in the $U s e$ of Words and the Mahāvyutpatti addresses translation of Buddhist texts and does not concern itself with the composition of literature of any kind in the Tibetan language. But if we are to grasp the historical contours of vernacularization in Tibet, we have to consider the impulse behind these interventions: the "making" of (Tibetan) vernacular culture in the image of the (here: Sanskrit) cosmopolitan is the making of a textualized culture fit for the properly authorized transmission of Buddhism. The literarization of the Tibetan language as intended by this intervention is the authorization of a language for the textualization of Buddhist literature. As Buddhist literature in India as well as in China had broadly speaking absorbed various literary conventions and expressive genres from a larger cultural environment, the transmission of Buddhism then also becomes a channel for wider-ranging cultural transfer.

Is Tibet a part of the Sanskrit cosmopolis? Pollock, for his part, remains guarded on this question. He touches upon Tibet on a few occasions, but ultimately remains ambivalent. In Pollock's main argument, the Sanskrit cosmopolis is formed not by war, conquest or religious mission, but rather by a "poetry of politics",56 a way of being political that "derived in some measure from the forms of expressivity and

56 Pollock 2006 [Anm. 18], p. 258. 
style that it deployed, from the cultural commitments it produced and helped to reproduce, and from the moral values from which these commitments sprang." 57 The spread of Sanskrit poetics across South and Southeast Asia is an important element in the formation of this cosmopolitan literary culture. Accordingly, Pollock observes that between 900 and 1300, the late seventh century treatise "Mirror of Poetry" (Kävyādarśa) by Dandin was studied and adapted from Sri Lanka to Tamil country to Tibet, as a kind of "globalized cultural commodity" that provided a framework for the theorization of vernacular poetries. ${ }^{58}$ The Mirror begins to be translated into Tibetan in the thirteenth century - around the same time and by the same scholar-monk as the lexicographical compendium Amarakośa -, and on these grounds Tibet can be said to have participated in the Sanskrit cosmopolitan order, although, as Pollock is quick to add, in a "more limited fashion" ${ }^{59}$ Elsewhere, however, Tibetan culture is said to occupy a space into which that order did not extend. ${ }^{60}$

Indeed, the first (partial) rendering of the Mirror of Poetry into Tibetan by the polymath Sa skya pandita Kun dga' rgyal mtshan (1182-1252) marks the beginning of a long-standing literary tradition in Tibetan belles-lettres. Hundreds of commentaries by Tibetan and Mongolian scholars were written on the eventually completed translation, setting standards for ornate composition in general, in verse as well as prose.$^{61}$ Lay aristocrats as well as scholar-monks engaged in the production of literature in the style of snyan ngag (Tibetan for Sanskrit kāvya) and of related discourse, although literary learning and practices remained more or less marginal in monastic curricula. A revival of Tibeto-Sanskritic kāvya in post-1950 Tibet shows that the genre was considered to be of lasting significance, ${ }^{62}$ though it is subject to an ongoing revaluation process within an emerging literary discourse that since the 1980 s situates Tibetan literature stronger within a paradigm dominated by Western literary concepts. ${ }^{63}$ But even prior to the twentieth century, Tibetan poetry is not confined to forms and styles adopted (and adapted) from kāvya. We have already mentioned versified songs, $g l u$ and $m g u r$, found in Old Tibetan documents. The poet-saint Mi la ras pa (1040-1123) firmly established the mgur genre, as one of the most popular and approachable forms of literary expression, not only among mystics and renowned yogic "madmen", but also among eminent scholar-monks. ${ }^{64}$ A genre of songs popular in late Indian Tantric Buddhism, the dohās, served as additional inspiration for Mi la ras pa's mgur poetry. When drawing attention to

57 Ibid., p. 258.

58 Ibid., p. 14, p. 21, and p. 28.

59 Ibid., p. 16, p. 399.

60 Ibid., p. 236.

61 VAN DER KuIjp 1996 [Anm. 51], Kapstein 2003 [Anm. 20].

62 KAPSTEIN 2003 [Anm. 20], p. 786-791.

63 Hartley, Lauran: Contextually Speaking: Tibetan Literary Discourse and Social Change in the People's Republic of China (1980-2000), Bloomington, Indiana 2003 (PhD dissertation), p. 16.

64 SøREnsen, Per K.: Divinity Secularized: An Inquiry into the Nature and Form of the Songs Ascribed to the Sixth Dalai Lama (Wiener Studien zur Tibetologie und Buddhismuskunde 25), Wien 1990, p. 14-17. 
kàvya in Tibet, therefore, Pollock indeed points to a key factor in Tibetan literary history and its discourse, but the role played by kävya in Tibetan literary identities needs to be addressed more broadly, and in consideration of other literary forms of expression that were prevalent in late Indian (Tantric) Buddhism.

But more importantly, our discussion of early Tibetan literization and literarization above has shown that literature in the Tibetan language was produced much earlier than the thirteenth century. Sa skya pandita may have given Tibetan literature and literary discourse a new direction, but he did not operate in a vacuum. It would be historically problematic, were to conceive of his poetological endeavours as marking a beginning of literature in the Tibetan language, or as a first impulse to make Tibetan a literary language. Even more importantly, to consider these endeavours only as operations relating to an aesthetic domain of expressive literature misses out on the larger concern that informs Sa skya pandita's entire range of scholarly activities: religion, the correct transmission and preservation of the Dharma ${ }^{65}$ For once they are considered in a larger context, Sa skya pandita's language-related endeavours can be understood almost like a scholarly "reenactment" of the older (imperial) regulatory impulse that drove the Use of Words, under radically different historical conditions.

Sa skya pandita lived during a period when Buddhism ceased to be a translocally significant cultural and intellectual presence on the Indian subcontinent. The long-term decline of Buddhism in India was in the twelfth century accelerated by the destruction of great monastic centres, with libraries, scriptoria, and seminaries, following the conquest of northern and eastern India by Afghan-Turkish Ghurids. Sa skya pandita's writings display a keen awareness of Buddhism's decline - an awareness that might on a very personal level have been him during his studies with the great Kashmiri scholar Śākyaśrïbhadra, who with an entourage of nine younger panditas fled to Tibet via Nepal, escaping a Muslim invasion to Bihar and Bengal under Muhammad Bakhtyar Khilji. ${ }^{66}$ Sa skya panḍita studied grammatical, philosophical and literary traditions of India with refugee scholars in Tibet. In the course of his scholarly career, he took to articulating and defending a comprehensive Indian-inspired ideal of scholarship in his "Entrance Gate for the Wise" (Mkhas pa rnams 'jug pa'i sgo). While encompassing language arts and sciences as well as logic, this ideal is circumscribed by the larger project of securing the proper interpretation of Buddhist doctrine. A widely cited verse from the closing section of the Entrance Gate succinctly conveys the fear of loss that the treatise

65 Pollock, justifiedly rejecting the undifferentiated invocation of religion as the main determinant in the spread of Sanskrit across South and Southeast Asia, has a tendency to downplay religious factors in vernacularization (see Bronner's review of POLLOCK 2006 [Anm. 18], where this point is problematized: BronNer, Yigal: A Road Map for Future Studies: The Language of the Gods in the World of Scholars, in: Comparative Studies of South Asia, Africa and the Middle East 31/2 (2011), p. 538-544).

66 This awareness is particularly clear in Sa skya pandita's letters, see the English translation of six letters as Part III of RнотоN, Jared: A Clear Differentiation of the Three Codes: Essential Distinctions among the Individual Liberation, Great Vehicle and Tantric Systems: the sDom gsum rab dbye and Six Letters, Albany, New York 2002. 
sets out to combat: "Nowadays this doctrine of the Sākya lion [i. e., the Buddha Śākyamuni] diminishes day by day, like a pond whose tributary streams have dried up". ${ }^{67}$ The refined language of snyan ngag/kävya has one of its main functions within the "community of interpreters" 68 of the Dharma that Tibetan scholars are to constitute in Sa skya pandita's view, providing a high cultural and literary standard for proper exegesis. A "buddhicization" of Sanskrit poetics is not only present in how Sa skya pandita conceives of the overall goal, purpose and context of literary composition, but also, as Jonathan Gold has elaborated, in an explicit reinterpretation of poetic emotions through the lense of Buddhist concepts. ${ }^{69}$

67 Mkhas 'jug III 77, translation from JACKsON 1987(2), p. 366.

68 Gold, Jonathan: The Dharma's Gatekeepers: Sakya Pandita on Buddhist Scholarship in Tibet, Albany, New York 2007, p. 118.

69 Ibid., chapter 6 . 


\title{
AbBREviations
}

\author{
PT Pelliot Tibétain
}

\section{BIBLIOGRAPHY}

Bronner, Yigal: A Road Map for Future Studies: The Language of the Gods in the World of Scholars, in: Comparative Studies of South Asia, Africa and the Middle East 31/2 (2011), p. 538-544.

Bushell, S. W.: The Early History of Tibet. From Chinese Sources, in: Journal of the Royal Asiatic Society of Great Britain and Ireland, New Series, Vol. 12, No. 4 (Oct. 1880), p. 435-541.

COMrIE, Bernard: Introduction, in: The World's Major Languages (Second Edition), ed. by Bernard Comrie, London/New York, p. 1-22.

Eimer, Helmut: Rnam thar rgyas pa. Materialien zu einer Biographie des Atiśa (Dipaṃkaraśrijñāna), Wiesbaden 1979.

DE Jong, Jan Willem: The Story of Rāma in Tibet: Text and Translation of the Tun-huang Manuscripts, Wiesbaden 1989.

Dotson, Brandon: Administration and Law in the Tibetan Empire: the Section on Law and State and its Old Tibetan Antecedents, London 2006 (PhD dissertation).

Dotson, Brandon: The Old Tibetan Annals: An Annotated Translation of Tibet's First History (Veröffentlichungen zur Sozialanthropologie 12), Wien 2009.

Dotson, Brandon: Theorising the King: Implicit and Explicit sources for the study of Tibetan Sacred Kingship, in: Revue d'Etudes Tibétaines 21 (2011), p. 83-103.

Dotson, Brandon/Helman-Ważny, Agnieszka: Codicology, Paleography, and Orthography of Early Tibetan Documents: Methods and a Case-Study (Wiener Studien zur Tibetologie und Buddhismuskunde 88), Wien 2016.

Ellingson, Terry Jay: The Mandala of Sound: Concepts and Sound Structures in Tibetan Ritual Music, Madison, Wisconsin 1979 (PhD Dissertation).

ForTe, Antonino: Political Propaganda and Ideology in China at the End of the Seventh Century, Napoli 1976.

GolD, Jonathan: The Dharma's Gatekeepers: Sakya Pandita on Buddhist Scholarship in Tibet, Albany, New York 2007.

Halkias, Georgios: Tibetan Buddhism Registered: A Catalogue From the Imperial Court of 'Phang Thang, in: The Eastern Buddhist 35/1-2 (2004), p. 46-105.

Hartley, Lauran: Contextually Speaking: Tibetan Literary Discourse and Social Change in the People's Republic of China (1980-2000), Bloomington, Indiana 2003 (PhD dissertation).

Hill, Nathan: An overview of old Tibetan synchronic phonology, in: Transactions of the Philological Society 108/2 (2010), p. 110-125.

IsHikaWA, Mie: A Critical Edition of the Sgra sbyor bam po gnyispa: An Old and Basic Commentary on the Mahãvyutpatti (Studia Tibetica 18), Tokyo 1990.

Iwao, Kazushi/Hill, Nathan/TakeuchI, Tsuguhito: Old Tibetan Inscriptions (Old Tibetan Documents Online Monograph Series II), Tokyo 2009.

JaCkson, David P.: The Entrance Gate for the Wise (Section III): Sa-skya Pandita on Indian and Tibetan Traditions of Pramāna and Philosophical Debate, 2 volumes (Wiener Studien zur Tibetologie und Buddhismuskunde 17), Wien 1987.

KAPSTEIN, Matthew: The Indian Literary Identity in Tibet, in: Literary Cultures in History: Reconstructions from South Asia, ed. by Sheldon Pollock, Berkeley/Los Angeles/London 2003, p. 747-802.

Kapstein, Matthew: The Tibetans, Malden/Oxford/Carlton 2006.

Kollmar-Paulenz, Karenina: The Buddhist Way into Tibet, in: The Spread of Buddhism, ed. by Anne Heirman/Stephan Peter Bumbacher, Leiden 2007, p. 303-340.

Kvaerne, Per: The Study of Bon in the West: Past, Present, and Future, in: New Horizons in Bon Studies (Bon Studies, No 2), Osaka 2000, p. 7-20. 
LAUfER, Berthold: Origin of Tibetan Writing, in: Journal of the American Oriental Society 38 (1918), p. 34-46.

LeE, Don Y: The History of Early Relations between China and Tibet: from Chiu t'ang-shu, a documentary survey, Bloomington, Indiana 1981.

LI, Fang Kuei/Coblin, Weldon South: A study of the old Tibetan inscriptions Taipei 1987.

NiedZIELSKI, Nancy: "Vernacular", in: Encyclopedia of Language and Linguistics, vol. 13, Tor-Z, Amsterdam/Heidelberg 2006, p. 414-415.

Panchen Lama: A Poisoned Arrow: The Secret Report of the 10th Panchen Lama. The full text of the Panchen Lama's 70,000 Character Petition of 1962, together with a selection of supporting historical documents (Tibet Information Network Background Briefing Paper 29) London 1997.

Panglung, Jampa: New Fragments of the sGra-sbyor bam-po gñis-pa, in: East and West 44(1), p. $161-$ 172.

Pollock, Sheldon: The Sanskrit Cosmopolis, 300-1300: Transculturation, Vernacularization, and the Question of Ideology, in: Ideology and Status of Sanskrit: Contributions to the History of the Sanskrit Language, ed. by Jan E. M. Houben, Leiden 1996, p. 197-247.

Pollock, Sheldon: The Cosmopolitan Vernacular, in: Journal of Asian Studies 57 (1998), p. 6-37.

Pollock, Sheldon: Cosmopolitan and Vernacular in History, in: Public Culture 12/3 (2000), p. 591625.

Pollock, Sheldon: The Language of the Gods in the World of Men. Sanskrit, Culture and Power in Premodern India, Berkeley 2006.

Rнотол, Jared: A Clear Differentiation of the Three Codes: Essential Distinctions among the Individual Liberation, Great Vehicle and Tantric Systems: the sDom gsum rab dbye and Six Letters, Albany, New York 2002.

Richardson, Hugh E.: A Corpus of Early Tibetan Inscriptions, London 1985.

Richardson, Hugh E.: Early Tibetan Law Concerning Dog-Bite, in: Bulletin of Tibetology 3 (1989), p. 5-10.

Scherrer-Schaub, Cristina: Enacting Words. A Diplomatic Analysis of the Imperial Decrees (bkas bcad) and their Application in the sGra sbyor bam po gñis pa Tradition, in: Journal of the International Association of Buddhist Studies 25/1-2 (2002), p. 263-340.

Scherrer-Schaub, Cristina: A Perusal of Early Tibetan Inscriptions in Light of the Buddhist World of the 7th to 9th Centuries A.D., in: Epigraphic Evidence in the Pre-Modern Buddhist World: Proceedings of the Eponymous Conference Held in Vienna, 14-15 Oct. 2011, ed. by Kurt Tropper (Wiener Studien zur Tibetologie und Buddhismuskunde 85), Wien 2014, p. 117-165.

Simonsson, Nils: Indo-tibetische Studien. Die Methoden der tibetischen Übersetzer, untersucht im Hinblick auf die Bedeutung ihrer Übersetzungen für die Sanskritphilologie, Uppsala 1957.

Skilling, Peter: From bKa' bstan bcos to bKa' 'gyur and bsTan 'gyur, in: Transmission of the Tibetan Canon. Papers Presented at a Panel of the 7th Seminar of the International Association for Tibetan Studies, Graz 1995, ed. by Helmut Eimer, Wien 1997, p. 87-112.

Sørensen, Per K.: Divinity Secularized: An Inquiry into the Nature and Form of the Songs Ascribed to the Sixth Dalai Lama (Wiener Studien zur Tibetologie und Buddhismuskunde 25), Wien 1990.

Sørensen, Per K.: Tibetan Buddhist Historiography: The Mirror Illuminating the Royal Genealogies, Wiesbaden 1994.

SteIn, Rolf A.: Tibetica Antiqua I: The Two Vocabularies of Indo-Tibetan and Sino-Tibetan Translations in the Dunhuang Manuscripts, in: Rolf Stein's Tibetica Antiqua, with additional materials, translated and edited by Arthur P. McKeown, p. 1-96. Originally published in French as: Tibetica Antiqua I: Les deux vocabulaires des traductions indo-tibétaines et sino-tibétaines dans les manuscrits TouenHouang, in: Bulletin de l'École Française d'Extrême-Orient LXXII (1983), p. 149-236.

STEINKellner, Ernst: A Literary Source for Late 18th Century Spoken Tibetan (Amdowa), in: Acta Orientalia Hungarica 34 (1980), p. 245-248.

Sun, Jackson T.-S.: Phonological Profile of Zhongu: A New Tibetan Dialect of Northern Sichuan, in: Language and Linguistics 4/4 (2003), p. 769-836.

TAKEUCHI, Tsuguhito. Formation and Transformation of Old Tibetan, in: Journal of Research Institute, Kobe City University of Foreign Studies 49 (2012), p. 3-17.

Tournadre, Nicolas and Sangda Dorje: Manual of Standard Tibetan. Language and Civilization, Ithaca, New York/Boulder, Colorado 2003. 
VAN DER KUijp, Leonard W. J.: Studies in the Life and Thought of Mkhas-Grub-Rje IV: Mkhas-GrubRje on Regionalisms and Dialects, in: Berliner Indologische Studien 2 (1986), p. 23-49.

VAN DER KUIJP, Leonard W. J.: Tibetan Belles-Lettres: the Influence of Daṇdin and Kșemendra, in: Tibetan Literature: Studies in Genre. Essays in Honor of Geshe Lhundup Sopa, ed. by José Ignacio Cabezón/Roger R. Jackson, Ithaca, New York 1996, p. 393-410.

van Schaik, Sam: A New Look at the Source of the Tibetan Script, in: New Studies of the Old Tibetan Documents: Philology, History, and Religion (Old Tibetan Documents Online Monograph Series III), ed. by Yoshiro Imaeda/Matthew Kapstein/Tsuguhito Takeuchi, Tokyo 2011, p. 45-96.

van SchaiK, Sam/IwaO, Kazushi: Fragments of the Testament of Ba from Dunhuang, in: Journal of the American Oriental Society 128.3 (2008), p. 477-487.

Wangdu, Pasang and Hildegard Diemberger: dBa' bzhed : the Royal Narrative Concerning the Bringing of the Buddha's Doctrine to Tibet (Beiträge zur Kultur- und Geistesgeschichte Asiens 37), Wien 2000.

ZeISLER, Bettina: Why Ladakhi must not be written - being part of the great tradition: another kind of global thinking, in: Lesser-Known Languages of South Asia: Status and Policies, Case Studies and Applications of Information Technology, ed. by Anju Saxena/Lars Borin, Berlin/New York 2005, p. 175-191.

ZeISLER, Bettina: On the Position of Ladakhi and Balti in the Tibetan Language Family, in: Ladakhi Histories: Local and Regional Perspectives, ed. by John Bray (Brill's Tibetan Studies Library 9), Leiden 2005, p. 41-64. 